\title{
Of God and Reason in XVIII C. British North America
}

\author{
Sobre Dios y la razón en la Norteamérica \\ británica dieciochesca
}

DOI: 10.32870/mycp.v10i28.701

Carlos Acosta Gastélum ${ }^{1}$

\begin{abstract}
The following article intends the description of the religious and intellectual environment in prerevolutionary America. It is divided into two main sections: (1) a religious one where I will cover the most significant elements, and the ideological context of what was the most decisive cultural force in the formation of the new country - Puritanism-; and (2) another that succinctly describes the particular shape that enlightened thought acquired in that part of the British Empire.

A description of eighteenth-century Puritan North America requires a closer look at the version of Calvinism prevalent in the Northeastern seaboard, and therein to the cultural phenomenon of religious revivalism. Now connected to these variables lie a series of theological conceptions that shaped Puritan belief and practice in manifold ways, and that will be covered in the first section of this work: Arminianism, Antinomianism, Millennialism, and Religious Enthusiasm, among others.
\end{abstract}

Keywords: Puritanism, Calvinism, Enlightenment, Revolution, Human Nature.

\section{Resumen}

El presente artículo tiene por objetivo la descripción del contexto religioso e intelectual de la Norteamérica prerrevolucionaria. Está dividido en dos secciones principales: (1) una religiosa en donde se abordarán los elementos más significativos y el contexto ideológico de lo que sería la fuerza cultural más decisiva en la formación del futuro país - puritanismo-, y (2) otra que de manera sucinta describirá la particular forma que el pensamiento ilustrado adquirió en esa región del Imperio británico.

Una descripción del puritanismo estadounidense dieciochesco nos obliga a un análisis del calvinismo característico de la costa nororiental, así como del fenómeno cultural de los avivamientos religiosos. Ahora bien, conectadas con estas variables yacen una serie de conceptos teológicos que moldearían la devoción y práctica puritana de diversas maneras, y que serán cubiertas en la primera sección del presente trabajo: arminianismo, antinomianismo, milenialismo y entusiasmo religioso, entre otros.

Palabras clave: puritanismo, calvinismo, Ilustración, revolución, naturaleza humana.

Artículo recibido el 28 de mayo de 2020 y dictaminado el 11 de septiembre de 2020.

1. Investigador independiente. Doctor en Filosofía, Universidad de York, Inglaterra. ORcID: https:// orcid.org/0000-0003-1543-3813. Correo electrónico: carlos.acosta.gastelum@hotmail.com 


\section{Theological Streams}

\subsection{Puritanism and revivalism}

At the beginning of the eighteenth century, religion in what was then British North America seemed ossified, lacking the original impetus that its earlier settlers had infused it with; particularly in the North-eastern colonies of New England (Congregationalists in Massachusetts and Connecticut) and in the middle colonies of New Jersey and Pennsylvania (Presbyterians), ${ }^{2}$ where $\mathrm{Pu}-$ ritanism had gained its strongest footing. Membership began to decline. The new Massachusetts Charter of 1691, which transformed the colony from a private and religiously oriented enterprise into a royal colony where franchise no longer depended on the religious profession, and a series of scandals (e.g. Salem in 1692) all eroded the prestige and credibility of Puritan institutions within the region (Brockway, 2003, pp. 9, 46, 201; McGrath, 2007, p. 155; Reichley, 1985, p. 61).

Perhaps even more decisive to the substantial changes in the religious landscape that ensued, the continuous and growing influx of immigrants into the hinterland ${ }^{3}$ - particularly of German Pietists in the Middle colonies of Pennsylvania and of Scotch-Irish Presbyterians coming from Northern Ireland (Ulster) - coupled with the rapid modernization of social and economic life in the colonies (Brockway, 2003, p. 33; Kelleter, 2009, p. 163), paved the road for the series of revivals that began in Northampton, Hampshire County in late 1734 "(what some historians termed the 'Little Awakening of 1735' [Gura,

2. The more moderate component within Puritanism was that of Presbyterianism, who endorsed an elective (and collegial) governing structure for the national church, and who used to think of themselves as the heart of the church of England; as the 'evangelical cutting edge of an inclusive national church' (Winship, 2011, pp. 691, 700, 705). They were Nonconformists who aspired to reform the government and some ceremonial aspects (viz., Catholic residues) of the Anglican Church (Winship, 2011, p. 692). They were thus generally opposed to the separatism that characterized their more radical brethren. Congregationalists on the other hand, believed in the right of local congregations to sovereignly decide doctrinal and ceremonial matters (McGrath, 2007, p. 137). As V. L. Parrington once put it, these individuals wanted to be ruled by neither bishop nor elder. Unlike Presbyterians, they were usually dismissive of 'ministerial expertise', and seemed to have been concerned of sinning through participation in the parish services, which led some of them to set up their own separate conventicles (Winship, 2011, pp. 695-696).

3. The colonial population not only moves substantially during the first two thirds of the eighteenth century, but rises from under 300,000 in 1700, to over 1'600,000 in 1760, and reaches 2’000,000 by 1770 (Ferguson, 1997, p. 50; Zinn, 2010, p. 49). 
2005, p. 71) and years later spread to the rest of the colonies. Other factors that contributed to this growing anxiety in the prerevolutionary colonial population were the still present fear of invasion or attack from the wilderness (the French and Indian Wars [1754-1760]), epidemics that periodically ravaged cities and towns (e.g. diphtheria alone kills between the years 1735-1737 over 20,000 people in the colonies), and as it is sadly common nowadays, economic modernization for those in the lower echelons of colonial society did not translate into an improved economic situation; in fact, by 1745 the colonies' standard of living reached its lowest point for that century (Ferguson, 1997, p. 50). Therefore, one distinguishing and defining feature of prerevolutionary revivalism is its emphasis on crisis (Ferguson, 1997).

Although it has always been a topic of contention among historians, especially since Jon Butler's publication in 1982 of Enthusiasm Described and Decried: The Great Awakening as Interpretative Fiction, we will side with those who prefer to consider them in hindsight as part of a single event and label them The (first) Great Awakening of the mid-1730s and early 1740s in colonial North America. But academic debates aside, massive religious gatherings (of up to 20,000 people at times) between 1735 and 1745 in New England reverted a downward trend in both assistance and church membership, and perhaps more consequential, in the role of religion in public life (McGrath, 2007, p. 57). It also endowed American religion with its evangelical ethos (e.g. a penchant for extempore preaching), and among its detractors, it fostered the 'proto-Unitarian tendencies' that eventuated during the following century (Brockway, 2003, p. 18).

The scope and impact of the revivals were greatly aided by 'two literary circumstances': (1) by the fact that the writings of famous revivalist preachers like Jonathan Edwards, Gilbert Tennent, or Samuel Davies were available to both popular and educated segments of the colonies, and in this respect, it is important to bear in mind that until 1765 religious publications in British North America outnumbered all other publications combined (Ferguson, 1997, p. 45, 53); and, of still greater significance for this work, (2) that these publications in defence of revivalism generated a response in kind, that is, literary, among those sectors of colonial society who were decidedly against them; of which probably the most eminent cases were those of Ebenezer Gay, Jonathan Mayhew, and Charles Chauncy — the last of these becoming thereafter Jonathan Edwards' main theological and cultural rival. 
As a clarifying note, way before the events just described, during the first decade of the eighteenth century, there was already a widening gap within Puritanism having to do with preaching style, notwithstanding the still prevailing doctrinal consensus among both Congregationalists and Presbyterians. Conservatives tended to favour a 'scholarly and restrained' approach, while others espoused a more emotional preaching style, one that more directly spoke to the emotions of its flock. Already too, a critical point of contention was a growing debate about the nature and spiritual reliability of 'sudden conversion experiences' which came to characterize the revivals a few years later (Brockway, 2003, p. 9). Thus, the philosophical principles of the experience of conversion and the roles assigned in it to emotions (affections) and reason became one of the main moot points in the religious debates of the time, as evidenced by the theological exchanges on this issue between Edwards and Chauncy.

Among the promoters of this new outlook and practice within Puritanism, Jonathan Edwards figures second to none not only on account of having been among the first to advocate a more emotional and less doctrinal approach to Calvinism, but also for becoming the most prolific and sophisticated apologist for the movement. Following the footsteps of his grandfather Solomon Stoddard, who perceived that the legalistic and rigid Calvinism endorsed by the New England establishment would not satiate the spiritual needs of people in a frontier context, Edwards advocated a religious praxis undoubtedly aimed at stirring the emotions of his parish. This Pietist thrust was encapsulated in the famous phrase first used by the Hernhutters in Saxony but adopted by revivalists ${ }^{4}$ in America: a religion of the heart; a renewed appreciation of the affections (emotions) and their role in spiritual conversion (Kelleter, 2009, p. 169; McGrath, 2007, p. 147; Reichley, 1985, p. 69).

An important consideration to bear in mind before continuing has to do with the nature of the Calvinism prevalent in the North American colonies in the seventeenth and eighteenth centuries. It was not classical or orthodox Calvinism (that of the Reformation) of the kind one would associate for example with the Institutes of the Christian Religion (1536), but rather the one found in the creeds of the Westminster Confession (1646) and regarded by historians as federal or covenant theology (Brockway, 2003, pp. 50-51). It was

4. Revivalism is, according to the definition given by Philip Gura (2005), 'the encouragement of religious renewal as communal experience' (p. 49). 
federal in the sense that God does not 'deal with humanity on an individual basis, but only through his federal representatives, Adam and Christ' (Brockway, 2003); and it was covenant ${ }^{5}$ for the belief that divinity's relationship with mankind has consisted in a series of contracts or compacts, of which the most important for our work is the so-called Covenant of Works between God and Adam - abrogated by Adam's disobedience and which render 'works' as meaningless for salvation, at least in the mind of theological determinists-, and the Covenant of Grace, brought about by Jesus' coming and through His sacrifice on the cross 'the promise of deliverance in the life to come' (Brockway, 2003, p.185).

It is also worth mentioning that contrary to popular opinion, Puritanism did not necessarily embody an 'authoritarian ethos' that insisted on regulating every aspect of daily life (Hall, 2002, p. 438); nor that it was a rigid and 'harshly imposed complex of beliefs that stifled all creativity and individual expression in its desire to enforce uniformity', but that it tolerated a certain degree of freedom and discord 'over the finer points of faith and practice' (Chamberlain, 1992, p. 336). Historical, geographical, social, and even structural (or ecclesiological) circumstances no doubt contributed to this doctrinal flexibility - in the absence of an 'external order' against which to react, theological self-definition became increasingly important-; the scattered nature, in a vast and poorly communicated region, of small congregations; the high literacy and disposition to debate theological issues among the population; and even the structure of Congregational churches, that 'undermined by design the imposition of any hierarchical authority', all contributed to this doctrinal flexibility (Chamberlain, 1992, pp.337, 339).

But before going any further, we need to advance both a definition and a brief history of Puritanism. It would certainly be difficult and misleading to offer a clear-cut definition of what Puritanism was. Such an effort would likewise run the risk of granting an unwarranted consistency to a faction or party within the Church of England that was markedly heterogeneous, and that acquired its sense of identity mainly in its opposition to an Anglican Es-

5. As many other theological components of Christianity, this idea of a covenant between God and mankind was bequeathed to early medieval Christianity by ancient Judaism (Cantor, 1994, p. 24). A plausible and interesting hypothesis stipulates that such theological construction had its origins in the markets of ancient Judea, though unlike commercial contracts of antiquity and today, this theological covenant is not freely-entered by all its participants, but was 'imposed by God' (Cantor, 1994). 
tablishment, and its desire for further reform of the national church (McGrath, 2007; Winship, 2011). As Michael Winship pithily remarked, 'Puritanism was more a problem generated by the structure of the Church of England than it was a free-standing entity' (p. 689). For these reasons any attempt to describe Puritanism in the American colonies forces upon us at least a brief historical digression to the beginnings of Protestantism in England.

The reasons that drove Henry VIII to a break-up with Rome are fairly well-known, and will not be taken up here; what is of concern for our purposes is to make it evident that the Reformation in England was, at least in its early stages, an entirely royal endeavour, viz., it was successively imposed from above by a series of monarchs on the English people - beginning with Henry VIII, continued and reinforced during the brief reign of Edward VI, and consolidated (and stabilized) by Elizabeth after a short-lived and ineffectual, yet ferocious Catholic reaction during Mary Tudor's reign (Gura, 2005, pp. 6-8; McGrath, 2007, pp. 107-126) —. But let us elaborate further on this.

It was only after Henry's death in 1547, during Edward's reign, that a conscious effort was made to align the reformation in England with the more Calvinist precepts of continental Europe, ${ }^{6}$ who had by then displaced Lutheranism as the chief driving force of Protestantism. Edward's untimely death, and the subsequent Catholic Restoration, meant that such reformative initiatives, never entirely popular, were short-lived (McGrath, 2007, pp. 113-118).

For her part, Elizabeth's main concern was to bring stability to a kingdom that was beginning to be torn by religious disputes. Despite her protestant leanings, she sought not to incense those important traditionalist sectors of her realm (McGrath, 2007, pp. 118-123). Those advocating for a more decisive reformation of the national church along Calvinistic lines were either offered small victories or, more commonly, promises of future fulfilment to their demands (McGrath, 2007, p. 125).

Finally, when James VI of Scotland came to power, Puritans believed that at last, their time had come, and this since James had supported the reforms of John Knox in Scotland, thereby creating a 'Reformed church along pure Genevan lines' (McGrath, 2007, p. 123). Politics, however, got in the way of

6. An example of this was Thomas Cranmer's (archbishop of Canterbury) invitation to prominent protestant theologians to settle in England: Peter Martyr Vermigli would be appointed to Oxford University as Regius Professor of Divinity, and Martin Bucer to the same position in Cambridge University (Hall, 1993, pp. 217-258; cited in McGrath, 2007). 
their plans, and when it became clear that James was to favour the via media followed by his royal predecessors, many of them began to reconsider the prospect of emigrating (McGrath, 2007, pp. 123-126). Some of them relocated to the main reformation centres of continental Europe like Geneva, Basel, Frankfurt, Strasbourg, or Amsterdam, as the Marian-exiles had temporarily done during the Catholic Restoration. Those Puritan pilgrim fathers that came to New England in the Mayflower at the beginning of the XVII $C$. for instance, were already in the third stage of their religious exodus - originally from Nottinghamshire, they had first moved to Amsterdam, and afterward to Leiden, till some of them, unwilling to go back to England or remain as aliens among the Dutch, decided to travel to America and start anew (McGrath, 2007, p. 152).

Out of the motley mesh of Puritan factions described before (McGrath, 2007; Winship, 2011) — and to which we must add that of the Baptists ${ }^{7}$ came the more than 4,000 individuals that, between 1627 and 1640, arrived on the shores of New England (McGrath, 2007; Winship, 2011). Most of the newcomers were not, however, Presbyterians, but more radical Puritans with a democratic ethos when it came to their outlook on church government (McGrath, 2007; Winship, 2011). Additionally, it appears that most Puritans of the time once settled in New England, abandoned a Presbyterian view of church polity for a more Congregational one instead (McGrath, 2007; Winship, 2011). But let us hark back to New England and the antinomianism that characterized revivalism.

Central in the revivalists' scheme was the concept of immediate grace, i.e., the idea (opposed to orthodox Calvinism) that the reception of divine grace by the convert occurred in a single, momentous, and identifiable occasion. With no need for intermediaries of any sort and after which the convert was a new creature; he had been born again due to the influx of grace rendered by the Holy Spirit (Kelleter, 2009, p. 166). It was precisely this understanding of the operation of divine grace that seemed so troublesome to orthodox $\mathrm{Pu}$ -

7. English Baptists trace their origins to John Smyth (1570-1612) who, like other Puritan dissidents fleeing persecution, migrated with some of his followers to Amsterdam in 1608 (Ammerman, 1995, p.19). Their name derives from Smyth's decision, after disclaiming scriptural support for infant baptism, to (re)baptize himself and some of his flock (Ammerman, 1995). In 1612 after disagreements with Smyth, some of these Baptists returned to England to establish the first Baptist church on English soil in the outskirts of London (Brackney, 1994: 5). The main features of this offshoot of Congregationalism are: (1) an insistence on a completely regenerated church membership; (2) a democratic form of church government, and (3) a denial of any significant distinction between laity and ministers (Brackney, 1994). 
ritans and could easily culminate, from their perspective, in enthusiasm and antinomianism (Robinson, 2011, p. 29). Enthusiasm refers to the belief in unmediated personal communication with God, but also to the more general outbursts of mass emotion that characterized the revivals, while antinomianism to the charge, commonly hurled to groups such as the Quakers and other Anabaptists, of believing that God manifests 'in impulses and impressions, [in] special revelations to individual persons' (Brockway, 2003, p. 187; May, 1970, p. 207); and, as previously mentioned, and particularly vexing to the patrician Puritans of the age, in their conviction that God does not operate through mediators like ministers or priests.

It was against this background of detractors and supporters of the awakenings, of Old Lights or Arminians (Old Sides for their Presbyterian allies in the Middle colonies) and New Lights (New Sides in New Jersey and Pennsylvania) or antinomians respectively, that the writings and sermons of Charles Chauncy, minister of Boston's prominent First Church, gained increased prestige and became, along with Jonathan Mayhew of Boston's West Church, the leader of the defenders of the New England Way: the Old Lights (Brockway, 2003, p. 10; Gura, 2005, p. 123; Robinson, 2011, p. 27).

\subsection{Arminianism, antinomianism \& millennialism}

In opposition to theological determinism or predestination that characterized orthodox Calvinism, Arminians, named after the Dutch theologian Jacobus Arminius (1560-1619), believed that human beings do have a role to play in the story of their eternal destinies. Through the exercise of free will, they can choose what is good and hence be among the elect. Therefore, for Arminians, Jesus' sacrifice on the cross is atonement in a universal sense, not just for the elect as orthodox Puritans would claim. Also, in a more general sense, Arminianism became a libel to be pronounced against anyone espousing or exhibiting any type of liberal thought or behavior in religion (Gura, 2005; Oakes, 2016, p. 40).

It is clear that from the mid-1720s onwards there was a rising tide of Arminianism in New England, particularly amongst the younger clergy, as evinced by what Robert Wilson called heresy trials directed against ministers with such theological proclivities (Oakes, 2016, pp. 41, 63; Wilson, 2015, p. 63; cited in Oakes, 2016). In this respect, the creation of ecclesiastical councils aimed at investigating the unorthodoxy of younger, Harvard-educated minis- 
ters like Benjamin Kent or Ammi Ruhammah Cutter is noteworthy examples (Oakes, 2016, pp. 44, 63). Yale had also seen its share of Arminian quarrelling amongst its ranks during the 'Great Apostasy' controversy of 1722 when most conspicuously its rector, Timothy Cutler, together with Samuel Johnson, and other colleagues, had defected to the Church of England (Oakes, 2016, p. 41).

But probably the most consequential and outspoken Arminian of this younger generation of ministers was Jonathan Mayhew, who throughout his entire published work, starting with his 'Seven Sermons' of 1748, stated his anti-Calvinist credentials many years before Chauncy mustered the necessary courage to make his theological positions public. In this work, for instance, Mayhew gave a clear moralistic tone to his exegesis regarding the fulfilment of moral duty as the "summum bonum' of true religion', and accordingly highlighted the moral character of Jesus' preaching in the Gospels (Oakes, 2016, pp. 51, 54).

Other important representatives of this generation of ministers with Arminian sympathies included Robert Breck, Ebenezer Gay, Samuel Mather, and William Balch, who became the subject of one of the most notorious controversies of the time, as well as one of the first Congregationalist ministers to state his views publicly. In this respect, Balch was a forerunner for Mayhew or Chauncy, who gained far more notoriety as 'pioneers of New England Arminianism' (Oakes, 2016, pp. 41, 45-46).

But Arminianism was not the only religious response in the face of Puritan theological determinism (i.e. Calvinistic predestinarianism). If Arminianism tended to be the stance of educated clergy (of Old Lights), revivalism came up with optimistic millennialism (Ferguson, 1997, pp. 51-52). Joseph Bellamy, sharing the millennial leanings of his mentor Edwards, writes in one of the most widely read sermons of the time (The Millenium [1758]) about how Christ's re-entrance into human history and His establishment of a thousandyear reign 'will change the nature and meaning of history' (Ferguson, 1997, p. 52); and in so doing, it will also erase the dreaded prospect of eternal damnation as the outcome of divine predestination. It is not unwarranted as well to speculate about the role that this millennialist optimism might have played in the growing sense of national identity and the ensuing call to arms that separation from England entailed; for as Robert Ferguson remarks, millennialist optimism 'pushes revivalism inexorably toward the notion of harmony and union in this world, and, for that purpose, toward the need for conviction and action by a united people' (Ferguson, 1997). Edwards, particularly 
in Some Thoughts Concerning the Present Revival [1743], is illustrative in this respect, but millennialist concerns were commonplace during the eighteenth century (Ferguson, 1997).

Antinomianism and Arminianism, 'the classical heresies of the Puritan tradition', deserve further attention, especially in the dialectical relationship that they have with each other as latent tendencies inherent to Puritan orthodoxy (Chamberlain, 1992, pp. 340-341). Among the divine attributes, Christianity has historically given preeminence to divine benevolence and omnipotence; and in their intention to dispose of the contradiction that seems to exist between them, theologians have emphasized or given relevance to one in detriment of the other. Orthodox Puritans for instance, and Reformed theology more generally, provide us with a picture of divinity that subordinates divine benevolence to divine omnipotence, and that claims to preserve the former by emphasizing 'the original goodness of created nature' (Chamberlain, 1992, p. 341).

Now this precarious equilibrium is clear to see in the Puritan quarrels over the process of redemption. Accordingly, orthodox divines, in their attempt to preserve the divine sovereignty through the redemption process, held fast to concepts such as free grace and solfidianism and presented a corresponding image of human nature that in its radical sinfulness is incapable of effecting its own salvation' (Chamberlain, 1992). The classical heresies in Puritanism just mentioned could thus be seen as exaggerations of tendencies inherent to Puritan doctrine, and hence defined accordingly: antinomianism, 'out of a desire to glorify God and debase the creature', unduly overestimates the role of divine grace in the salvation process to the extent that it makes us mere spectators in the drama of our redemption. Contrastingly, by empowering our capacity for achieving our salvation, Arminianism appears to lose sight of the divine initiative, with the result that 'redemption becomes the product not of God's good pleasure but [solely] of a human effort' (Chamberlain, 1992, p. 432).

\subsection{Ethical concerns}

To be sure, the issues that disturbed most Old Lights had to do with the behaviour displayed by the revivalists that tended to unsettle traditional church structure and order. As Philip Gura (2005) explains, the attack of Old Lights tended to revolve around three topics: (1) the conduct of itinerant preachers 
and lay exhorters, that is, people without formal training in pastoral duties and who embarked in preaching and exhorting; ${ }^{8}$ (2) the antinomian tendency observed in the converts of the awakenings, and this associated with the concomitant tendency to rash judgment as to the spiritual state of other people, particularly aimed at what they regarded as unconverted ministers (those having not experienced a spiritual rebirth); and (3) the excessive emotionalism of the awakened (p. 111).

But there were certainly other, more ethical objections raised by Old Lights against the behaviour displayed by revivalist preachers. Ava Chamberlain, drawing on the work of the political theorist Judith Shklar, argues that the post-awakening Arminian ascendancy in New England was driven, to a large extent, by a revulsion to cruelty; cruelty to be found not only in the uncharitable behaviour of these itinerant preachers but as well in some key aspects of Puritan doctrine like double predestination or total depravity (1992, p. 347). Making use of Shklar's concept of 'ordinary vices', she claims that the premodern moral world of Puritanism, with its emphasis on sin against God (and therein with pride as the chief transgression) tended to downplay more 'ordinary vices' (or sins) like cruelty, hypocrisy, treachery, snobbery, or misanthropy (Shklar, 1984, p. 2; cited in Chamberlain, 1992). Chamberlain claims that the appearance of cruelty and hypocrisy in revivalism - cruelty that Chauncy saw for example, in the rhetoric of the revivalist preachers and their use of terror; and hypocrisy evinced not only in the censoriousness displayed by these itinerants against established ministers, but as well in the many he had believed to have been converted during the revivals, but that he saw going swiftly to their old ways - is central to explicating a 'new sensitivity... [against] cruelty in orthodox Puritanism, [that] culminated some ten years later in an unabashed support for Arminianism by such prominent divines as Charles Chauncy, Jonathan Mayhew, and Ebenezer Gay' (Chamberlain, 1992, p. 347). Now one of the fortunate outcomes of the revivalists' quarrels over ministerial preaching style and training was the creation of a series of educational institutions throughout the colonies during the middle and second half of the century. As expected, New Lights took the initiative by founding

8. For instance, one of the most popular sermons of the period - The Danger of an Unconverted Ministry [1740] — by Gilbert Tennent, likens those ministers opposed to the revivals to Pharisees and blames them for lacking the courage or 'honesty to thrust the Nail of Terror into sleeping souls' (Tennent, 1740; cited in Ferguson, 1997, p. 54). 
the College of New Jersey (later Princeton University) in 1746. As a response, Anglicans established King's College (afterward Columbia University) in New York in 1754. In 1764, Brown University commenced as a Baptist enterprise in Rhode Island. And in 1776, Dutch New Lights constituted Queen's College, later Rutgers University in New Jersey (Ferguson, 1997, p. 57).

Since, as we have explained, the concept of conversion (of being born again) through immediate grace was cardinal to the revivals, it is necessary to say a few more words about it, as well as the doctrinal or dogmatic context in which it operated: Puritanism and Evangelicalism. Theologically, the sources of Puritanism include, along with Calvin, the writings of the apostle Paul and those of Augustine (354-430) (Brockway, 2003, p. 180). All of their soteriologies give an uppermost relevance to the concept of New Birth, and all three also are predestinarians, ${ }^{9}$ i.e., they hold to the notion that God has decided or predestined all persons to 'either damnation or redemption' (Brockway, 2003). In this scheme, the pious actions of human beings are of no consequence to the decrees of divinity. Redemption comes, if at all, through a free and largely unmerited gift of grace endowed by the Holy Ghost.

And having in mind the Anglo-American political tensions of the time, we have to mention other intellectual sources of Puritanism, such as its inherent aversion to centralized authority, its primitivism, 'the legalism of covenant theology, and biblical exegesis as a regular cultural practice' (Ferguson, 1997, p. 46). Such sources, according to many, lend themselves easily to oppositional rhetoric, and do so, among other reasons, because a Puritan conversion experience 'ritually exposes the sinful heart to public judgment' as well as it 'relates individual morality to communal prosperity in compulsive ways' (Ferguson, 1997). Under such an ideological framework, the prospect of identifying and resisting an 'unworthy leadership' becomes more tenable (Ferguson, 1997).

As for evangelicalism, it is customary among historians to regard the awakenings as the crucial period when religion in that part of the world acquired its characteristic evangelical ethos, exemplified by the enormous gains in membership that sects like the Methodists and Baptists reaped during those years. And since sudden, dramatic conversions - of the kind epitomized by Paul and his conversion on the road to Damascus, or of Augustine's touching

9. While most Christian theologians would bracket the apostle Paul in this predestinarian category with the likes of Augustine or Calvin, there are other scholars that picture Paul as nothing less than a soteriological universalist (e.g. John Hick). 
conversion scene that we encounter in his Confessions - constitute one, if not the most fundamental aspect of evangelical religion, we must mention here the stages of what an evangelical religious experience consists in: 'conviction, conversion, and sanctification' (Brockway, 2003, p. 65). A process encountered in virtually all examples given by Edwards in his Faithfull Narrative of the Surprising Work of God in the Conversion of Many Hundred Souls (1737), the work that catapulted him from provincial irrelevance to 'the chief American spokesperson for transatlantic evangelism' (Gura, 2005, pp. 79, 85).

For his part, the Great Awakening had convinced Chauncy that New England theology required revision, for he believed that theology that insisted so severely in God's rejection of human depravity and that moreover 'hammered home the [high] probability of damnation' for everyone, 'lent itself by its very nature to abuse' (Griffin, 1980, p. 110). If social and ecclesiastical disorder were the assured outcomes of an emotional religious reaction to dour Calvinism, then the tenets themselves might need some revision (Griffin, 1980). Thus, between the years 1745 and 1761 Chauncy embarked on the task of creating a new 'body of divinity' which he hoped would preclude the appearance of other would-be Edwards or Whitefields, whom he believed preyed on the fears and irrationality that he saw as the quid of New Light theology (Griffin, 1980, p. 110). In this task, however, he did not entirely reject his Puritan heritage, as the influence of theologians like Richard Baxter or John Taylor evinces, but it is clear that, as Norman Gibbs (1992) remarked, Chauncy was also open to eighteenth-century optimism.

A theological optimism discernible not only in the deism that characterized most of the revolutionary leadership, or in the Arminianism of Old Light clergy just described, but also in the increasingly popular view described by Conrad Wright as Supernatural Rationalism - 'the belief that intuition, experience, and reason will all prove to complement and confirm, rather than displace, the Christian revelation' (May, 1970, p. 208)—. Again, Chauncy is illustrative in this respect as he repeatedly peddles for what he terms a religion of the understanding; as one where the emotions are to be regarded as lesser and as subordinate to the nobler operations of the intellect (Chauncy, 1743, pp. 2, 418, 419, 422).

Before moving to our analysis of the intellectual and political climate of those years, it is worth mentioning here as well what became the most significant theological debate in British North America in those years: the debate about the doctrine of Original Sin. It was the work of the dissenting 
English theologian John Taylor (1694-1761) and his reinterpretation of the moral condition of the first couple - one in which, unlike orthodox Puritan belief, they were not the beneficiaries of the preternatural gift of original righteousness ${ }^{10}$ but would be more accurately described as in a condition of moral primitiveness - that precipitated the rebuttals of defenders of the ancient doctrine, chief among them Edwards (The Great Christian Doctrine of Original Sin Defended [1758]) (Griffin, 1980, pp. 121-122; Oakes, 2016, pp. 62-63; Robinson, 2011, p. 28). Symptomatic of the theological times, in a relatively short period time New England divines would pass from unanimous adherence to orthodoxy in this doctrine before 1750 to considerable modifications 'by some of the most liberal thinkers' (Smith, 1955, p. 1; cited in Griffin, 1980).

\section{Enlightenment and Politics}

An overview of the cultural context of British North America in the eighteenth century must also take into account two variables of relevance -one intellectual and the other political-, both of them closely linked to each other, as well as to the Puritan religion that was the outcome of seventeenth-century New England: the Enlightenment, in the particular shape it took in that part of the British Empire, and the war of independence that in many respects officialised the relative autonomy of the North American colonies.

Americans receive, or better yet, borrow enlightened ideas within a context of political conflict with London. Therefore, unlike the European Enlightenment and its belated sense of urgency and historical crisis, their Enlightenment 'begins in the political arena, where it unleashes the earliest recognitions of stress and disjuncture' (Ferguson, 1997, p. 38); i.e., it is not 'the celebration of knowledge' so much as the 'struggle towards realization',

10. The Catholic narrative of the Fall -largely as encountered in the Council of Trent, itself heavily reflecting medieval Scholastic theology-, besides favouring a consideration of it as an actual event in time, argues that the Fall did not corrupt human nature entirely, but that what was lost by the first couple, and for their posterity as well, was a sort of preternatural gift that purportedly enabled the first humans to always properly order their inclinations so as to always abstain from sinning; i.e., 'an ordering of the powers of the human soul, and body, such that all of them, including all the emotions and desires and all the functions of the body, obeyed the highest part of the soul, the reason' (Adams, 1999, p. 235). 
towards a national and political realization that is, that gives significance to American enlightened thought (Ferguson, 1997, p. 41).

The first thing to be addressed then is the definition of the type of Enlightenment one is warranted to speak of when discussing late eighteenthcentury North America. And if, as most historians have usually done, we draw a distinction between a moderate or conservative sort of enlightened thought —associated with British thinkers like Locke, Newton, Clarke, Hutcheson, and even further back with Bacon-, and a more egalitarian and materialistic Radical Enlightenment identified with French philosophers like Diderot, Bayle or Rousseau, it is widely accepted among scholars that the former, more aristocratic sort of Enlightenment gained fairly early the upper hand among the colonial elite (Israel, 2006, p. 531; May, 1970, p. 210).

Now such distinction surely sheds some light on the type of government these colonial patricians created a few years after their first skirmishes with the English. Far from the emancipatory character of the enlightened French radicalism that began after 1750 , Newton, Hutcheson, and most definitely Locke, were all social (and in Locke's case even theological) ${ }^{11}$ conservatives (Israel, 2006, p. 528). These British thinkers consistently opposed the 'egalitarian, democratic, republican, and anticolonial thought' that we now associate with progressive political movements (Israel, 2006).

It is not my intention here to belittle a thinker of the magnitude of Locke, who bequeathed to philosophical posterity such weighty contributions as epistemological empiricism for instance. But it would not be a sort of anachronistic historical crime to also mention that he had a rather qualified conception of political and religious tolerance; that his attitudes towards non-whites were

11. To prevent the charge of uncharitable behaviour against Locke here, I believe the following words are in order. Though it is true that by 1667 Locke had already expressed misgivings about the effectiveness of coercion in matters of religious conviction - the coercion of belief was futile in his view 'since coercion acts upon the will, and belief is not a voluntary matter' (Dunn, 2003, p. 275) - , the toleration he advocated was circumscribed to Protestant Nonconformists, leaving expressly outside of such leniency Catholics, atheists, and 'Mahometans' (Dunn, 2003, p. 273; Shapiro, 2003, p. 319). His reasons for doing so were, however, not religious but political. Atheists could not be trusted because '[p]romises, covenants and oaths, which are the bonds of human society, can have no hold upon an atheist' (Locke, 2003, p. 246). Moreover, those who have no 'pretence of religion' can have no claim to the 'privilege of [such] a toleration' (Locke, 2003). As for Catholics and Muslims, they are not to be tolerated since their allegiance lies with a foreign power (Shapiro, 2003, p. 319); 'That church can have no right to be tolerated by the magistrate' that is so constituted that 'all those who enter into it, do thereby, ipso facto, deliver themselves up to the protection and service of another prince' (Locke, 2003, p. 245). 
far from humane - he always, for instance, supported the appropriation of Indian lands in the colonies, and was never an advocate of manumission (Israel, 2006, p. 529)—; or that he was always an unabashed partisan of big property: in the Carolinas constitutions which he drafted (1660), he established a quasi-feudal aristocratic system where more than forty percent of the colony's land was concentrated in the hands of 'eight barons', and where, moreover, only one of such barons was entitled to hold office as governor (Zinn, 2010, p. 47). This emphasis on Locke is not gratuitous, for as it is widely acknowledged, most of the leading revolutionaries were Lockeians, and he is thus correctly regarded as the 'philosophical father of the Founding Fathers and the American system', and more generally, as 'America's philosopher' (Dunn, 2003, p. 260; May, 1970, p. 203; Zinn, 2010, p. 47).

American intellectuals of the time, despite their penchant for enlightened ideas, are not so much concerned with the provenance or with the 'details of systems of thought', but with the adaptation and application of those ideas in a context of a new world and elitist republicanism (Ferguson, 1997, pp. 34-35). This strange blend of 'decontextualized thought' and of yet sincere belief in abstractions is made evident by the writings of the leaders of the American political revolt such as Thomas Jefferson (e.g. The Declaration of Independence [1776]) (Ferguson, 1997). This however should not be understood as an outright American rejection of intellectual traditions or as mere opportunism as Robert Ferguson remarks, but there is definitely, one could argue, a pragmatic and utilitarian approach to the way in which colonial intellectuals select, appropriate, and recast those ideas that would better suit with their political and social needs. These are the beginnings of an intellectual tradition in North America that shuns all major social and philosophical systems of thought, without a real centre of intellectual gravity.

So, from what foreign intellectual currents did they borrow? From England, Lockean political philosophy, epistemology, and psychology; 'Newtonian science [...] the Whig theory of history (...) and the rights of English subjects' (Ferguson, 1997, pp. 35-36; May, 1970). From France, 'a distrust of organized religion', the concept of the man of science or philosophe as citizen of the world, and 'a belief in a natural order' (Ferguson, 1997, pp. 35-36). From Scotland, the conservative tendency, plain to see in the political writings of the time in the colonies, to furnish 'a secular vocabulary that nevertheless keeps providence safely in mind' (Ferguson, 1997, p. 36); an emphasis on the importance of public education, and the ideological basis for a colony's right 
to revolt (Skinner, 1993). And from continental natural lawyers (e.g. Grotius, von Pufendorf, Burlamaqui or Vattel) the idea of a government that is the outcome of a contract or 'compact under the law' (Ferguson, 1997, p. 36); and naturally, natural law.

Now such contractual outlook on government is clearly connected to the Calvinistic concept of covenant already alluded to, which states that divinity's relationship with His human creatures has consisted in a series of contracts established throughout history. This notion of a conditioned loyalty, of a contract established between the authorities and those governed that could be abridged by the latter in the case of a breach of obligations on the part of the former, is a cornerstone of American political thought ${ }^{12}$ (Wald, 1992).

As for natural law, there is a definite strand of such legal reasoning in the moral and theological rationale of Old Lights like Chauncy or Mayhew. While some have attributed this to Chauncy's acquaintance with the moral philosophers of the Scottish Enlightenment - some of which have a distant kinship with natural law-, it is worth mentioning that 'Grotian ideas of natural law' were fairly known in the English-speaking world of the time, including British North America (Cox, 1987, pp. 386-387; Haakonssen, 1985, p. 48). Moreover, natural law ideas of Germanic and Swiss writers like Pufendorf, Vattel or Burlamaqui, were commonly used in conjunction with conventional English law in both Britain and North America (Haakonssen, 1985, p. 48). And it might not be unwarranted on our part to draw a parallel —albeit with considerable provisions for differences in context and time- between how a Grotian appeal of natural law was part of a more general 'Arminian contribution to the upsurge of religious and ethical rationalism in the face of orthodox

12. The break with the Pauline outlook of unconditional obedience to civil authorities took place during the middle of the sixteenth century, when Lutherans and Calvinists, in the face of a growing Catholic reaction threat, were forced to formulate a theoretical alternative that would warrant a right to revolt against authorities that attempted to exterminate them. During the first stage of such theoretical construction, it was the Lutherans who seized the initiative and their arguments tended to revolve around two sources: (1) in Saxon private law and which stipulated the legitimacy of resisting unlawful (or unfair) state force; and (2) Hessian constitutionalist theory that located rightful resistance to unlawful state force in 'subordinate magistrates'. Calvin's ingenuity consisted in the introduction of the concept of popular magistracy, and thereby by bequeathing this historical (as well as secular and constitutional) conceptual tool to his Huguenot followers, he enabled them to widen their support base by presenting their case in juridical and historical, and not only in sectarian, terms (Skinner, 1993, pp. 203, 204, 217, 241, 243; Forrester, 1987, p. 357). It is difficult to overstate the significance and influence of these developments for John Locke's Two Treatises of Government (1680), 'the classical textbook of radical Calvinistic politics' (Skinner, 1993, p. 246). 
Calvinism' and antinomianism in England, and a North American colonial context that, as we have seen, was likewise reacting to both dour Calvinistic dogma and antinomianism (Haakonssen, 1985).

Despite the common distrust towards organized religion between the American and the French Enlightenment, it is evident that North American intellectuals availed themselves of religious topics and vocabulary to advance their political agenda. They find it both safer and more effective to at least couch their social and political concerns in religious language. Thus, one of the distinctive features of the American Enlightenment is that it rests in the common or shared rhythms and patterns that the Enlightenment has taken from Christianity' (Ferguson, 1997, p. 42). In this manner the Congregational dislike for centralized authority and its strong belief in self-government pairs the enlightened 'use of reason against mere authority' (Ferguson, 1997, p. 43). In sum, there is simply no way of understanding this period of American history without recognizing this 'interplay between religion and politics as a source of liberty' (Ferguson, 1997, p. 45).

Now this antiauthoritarian religious bent is plain to see in the apprehensions generated by the prospect of the establishment of an American Episcopacy, fears that reached their zenith between the years 1767-1770 and brought about significant acrimony throughout the colonies against the Church of England (Ferguson, 1997, p. 47). And as proof of its significance, it fostered even more publications than the Stamp Act dispute ever did (Ferguson, 1997). It is hence correct to regard such fears, however unfounded they might have been, as one of the chief factors in the ensuing revolt against England.

It is in this embattled context once again that Chauncy gains notoriety by becoming the most vocal minister in the struggle against the Church of England in this matter (Ferguson, 1997). Though it is likewise true that the publications written for that purpose served other aims as well, such as that of identification beyond religious lines, of ministers that tended to share a general political outlook that could be best described as separatist; i.e., tracts like Chauncy's A Letter to a Friend [1767] not only served the cause of antiepiscopacy, but are used by ministers and their readers to 'recognize each other across denominational affiliations' (Ferguson, 1997). Such publications, moreover, played a crucial role in the growing 'colonial self-recognition' in the years before the war with England, and one recurrent device for doing so is by portraying Britain in the most ominous terms possible. Again, Chauncy is illustrative in this respect, and the dichotomies he relies on usually posit 
an innocent and virtuous America, against a corrupted England; between 'American piety' and 'British manipulation'; in sum, the whole contrast is reduced to a confrontation of good versus evil (Ferguson, 1997, p. 48). And under the context of liberty of conscience that made ecclesiastical differences permissible in the colonies, Chauncy can excoriate British culture and yet remain free of political charges of dissent (Ferguson, 1997). In any case, for the upper echelons of the Anglo-American society of the time, the biggest concern was not heresy, but treason (Ferguson, 1997).

So, when it came to organized religion, what were the attitudes or positions of the alternatives available in colonial society towards the new learning? To begin with, it is important to belie the assumption that Calvinism was an enemy of the Enlightenment; as a sort of monolithic opponent to it. While New Light Calvinism, and popular revivalism, in particular, could be portrayed as inimical to enlightened thought in the colonies, Old Lights like Chauncy or Jonathan Mayhew for instance, were more open to eighteenthcentury theological optimism and its more progressive ethical outlook (May, 1970, p. 207). Likewise, lest we forget, 'the main citadels of New England Puritanism' - and therein the intellectual circles around Congregational Harvard and Presbyterian Princeton- were points of entry of Locke and the Scottish Enlightenment (May, 1970). Moreover, although a significant part of the revolutionary leaders thought of themselves as deists, it was the Calvinist clergy the most steadfast supporter of political independence (May, 1970, p. 202).

It seems fitting at this point to introduce a brief parenthesis to consider the phenomenon of deism, which, though more an attitude of skepticism towards organized religion than a system of faith in its own right, did, as mentioned before, prove to be of some significance for educated segments of society in the north-eastern cities, as evinced by its influence on some leaders of the American political revolt like Thomas Jefferson, James Madison, and Thomas Paine (Fischer, 2010, p. 15).

In opposition to theistic conceptions of divinity, deism conceives of a benevolent, yet distant creator; a heavenly architect or primum movens that after bringing about the existence of everything there is, distances Himself from it (Fischer, 2010, p. 14; Flint, 1988). A glaring divergence with theistic conceptions of divinity then has to do with the degree to which this deity is said to concern Himself with the fate of the beings He created, i.e., with divine providence. While the traditional Christian understanding of providence is 
rather strong (Particular Providence) — and certainly therein the unqualified determinism encountered in orthodox Calvinism-, the deistic account of divine providence is 'general' in character (Flint, 1988). By 'particular' or 'meticulous' providence we are to understand that divinity ordains (and controls) all events (Rhoda, 2010, p. 283). By contrast, the deistic conception of general providence is not meticulous in the sense that once the machinery (persons, circumstances, etc.) has been set in motion, divinity is not concerned anymore with whatever happens afterward. The deist's Supreme Being then does not disrupt the natural laws through miracles, nor in special revelations to specific individuals (Fischer, 2010, p. 14). But this should be no cause for concern according to this ideological framework since the Creator has endowed mankind with everything needed to attain happiness: above all, intelligence, and an innate morality (Fischer, 2010).

Deists furthermore rejected the idea of the divine inspiration of Scripture, the Christian understanding of Atonement, and in stark contrast to Calvinistic dogma, the idea that human nature is inherently or originally flawed (Fischer, 2010).

Beyond the revolutionary leadership previously mentioned, other illustrious deists of the time included figures like Benjamin Franklin, Ethan Allen, and Elihu Palmer; the last of these being probably the most candid and radical in his opinions, as well as the most important of its publicists (Fischer, 2010, p. 15). It was Palmer for instance, who toured the country giving 'lectures and founding deist societies' (Fischer, 2010, p. 14). And it was Palmer as well who wrote the best-known deist work on American soil in 1801 - 'Principles of Nature: or A Development of the Moral Causes of Happiness and Misery among the Human Species' (Fischer, 2010)—. In this book Palmer openly cites the provenance of his ideas: mainly in the work of English deists like John Toland, and Anthony Collins, and those of French materialists like D'Holbach or La Mettrie (Fischer, 2010, p. 18). Palmer likewise founded the first deist newspaper in America ('The Temple of Reason') which regularly published scathing criticisms of Christian dogma. It served also as a vehicle for more radical views as it regularly 'reprinted excerpts from French philosophers such as Voltaire, Rousseau, Volney, and Condorcet' (Fischer, 2010). Let us now go back to organized religion and its relationship to the new learning.

As for 'papists', before 1763 and certainly once again after the revolutionary endeavour had been secured, Catholicism was usually portrayed as a cultural adversary of the American Enlightenment, and to the idea of progress 
more generally (May, 1970, pp. 205-206). It is more difficult, however, to advance a definitive assessment on Anglicanism's relation to the Enlightenment in eighteenth-century North America; for though it is true that after 1763 many in the colonies regarded the Church of England as the embodiment of tyranny and aristocratic privilege, it is important to bear in mind that Arminianism and Latitudinarianism were significant forces within the Anglican church of the time (May, 1970, p. 206; Oakes, 2016). Further evidence of this more liberal stance of Anglicanism in America as pertains to human nature and its possibilities, were the various defections of Congregationalist ministers with Arminian sympathies to its ranks (Oakes, 2016).

Lastly, there is another important and pervasive component of American anthropology that was already at display in the second half of the eighteenth century and with important implications for the shape of the future independent government. A pronouncement or judgment that, as mentioned before, has been historically tied to Calvinism, but that also found secular expression in the work of Hobbes: Anthropological Pessimism.

In its religious form, Augustine, the fountainhead of this tradition, held a rather negative appraisal of human nature; an appraisal that in opposition to classical culture, conceives of man as essentially morally flawed, ${ }^{13}$ as unable to bring about through his efforts his moral betterment, let alone his redemption ${ }^{14}$ (Cantor, 1994, pp. 75-76; Helm, 2009, p. 157). But it is also true that, as Richard Hofstadter once remarked, the colonial elite - particularly the architects of the country to be- were also heirs to 'seventeenth-century English republicanism' (Hofstadter, 1960, p. 5). They shared Hobbes' (and Calvin's) prognosis on human nature, but certainly parted ways with him on the political prescription: though they believed men to be essentially selfcentred, rapacious creatures dominated by their passions, they feared tyrannical rule just as much as they abhorred what they regarded as the tyranny of the masses (Hofstadter, 1960).

13. The classical position (Greek and Roman) on this matter was derived from Platonic ideas on morality and ethics, and it entailed the view that ignorance is the source of evil, and that therefore men, through apposite rearing, could be taught to become good men (Cantor, 1994, pp. 75-76).

14. Calvin (as Augustine) drew a distinction between intellect and will, and argued that although a person may correctly appreciate a given moral situation (intellect), his will is bound and corrupted in such a radical manner that 'it can choose nothing but evil, even if it does so of its own accord and gladly without being driven by any external impulse' (Calvin, 1996, p. 69; cited in Helm, 2009). 
In this work, we have attested that consonant with the times, there was a revindication - after more than a century of Calvinistic anthropology - of the capacity of rational creatures, qua moral agents, to both discern in whatever moral circumstances what was demanded of them by their religious convictions (intellect), and to act accordingly (will). A rational tendency in theology expressed in misgivings or outright rejections of certain core tenets of Calvinism such as unconditional election or total depravity, as well as the adoption of more synergistic soteriological frameworks (e.g. Mayhew, Chauncy, etc.). In sum, there was a shift from an emphasis on human depravity, to human capacity. A momentous shift for understanding some of the currents in American thought of the following century such as Transcendentalism, Universalism, and Unitarianism (Robinson, 2011).

Such tendency, however, was circumscribed to small, and usually upwardly mobile sectors of New England society; the rest of the population embracing (in varying degrees) the emotionalism and antinomianism associated with religious revivalism. The seeds therefore of the major divide in American religion between a socially-conservative, science-skeptical evangelical camp, and what could be loosely described as liberal Christianity, were sown in the years that this work has covered, and which were crucial in the evolution of American religion.

Our main aim, in what has been said so far, has been to sketch an overall picture of the intellectual environment of late eighteenth-century colonial (and afterward independent) America. And in doing so to also bring to the reader's attention the original presence, and continuing significance of religious conceptions in American political discourse and practice, as well as in the more general cultural foundations of that country. To neglect such an important variable owing to academic/secular, or more generally to 'modern' prejudices, is to be done at one's peril and at the risk of having an incomplete picture of the relevant forces at operation in American society at any given time.

\section{References}

Adams, R. M. (1999). Original Sin: A Study in the Interaction of Philosophy and Theology in O. Crisp (Ed.), A Reader in Contemporary Philosophical Theology. T\&T Clark.

Ammerman, N. (1995). Baptist Battles: Social Change and Religious Conflict in the Southern Baptist Convention. Rutgers University Press. 
Brackney, W. H. (1994). The Baptists. Praeger Publishers.

Brockway, R. W. (2003). A Wonderful Work of God: Puritanism and the Great Awakening. Lehigh University Press.

Cantor, N. F. (1994). The Civilization of the Middle Ages: A Completely Revised and Expanded Edition of Medieval History. HarperCollins Publishers.

Chamberlain, A. (1992). The Theology of Cruelty: A New Look at the Rise of Arminianism in Eighteenth-Century New England. The Harvard Theological Review, 85(3), 335-356. https://doi.org/10.1017/S0017816000003345

Chauncy, C. (1743). Seasonable Thoughts on the State of Religion in New-England. Rogers and Fowle for Samuel Eliot.

Cox, R. H. (1987). Hugo Grotius in L. Strauss, \& J. Cropsey (Eds.), History of Political Philosophy. The University of Chicago Press.

Dunn, J. (2003). 'Measuring Locke's Shadow in J. Locke (Ed.), Two Treatises of Government and A Letter Concerning Toleration. Yale University Press.

Ferguson, R. A. (1997). The American Enlightenment: 1750-1820. Harvard University Press.

Fischer, K. (2010). Religion Governed by Terror: A Deist Critique of Fearful Christianity in the Early American Republic. Revue Française d'Etudes Américaines, (125), 13-26.

Flint, T. P. (1988). Two Accounts of Providence in T. V. Morris (Ed.), Divine and Human Action: Essays in the Metaphysics of Theism. Cornell University Press.

Forrester, D. B. (1987). Richard Hooker in L. Strauss, \& J. Cropsey (Eds.), History of Political Philosophy. The University of Chicago Press.

Gibbs, N. B., \& Gibbs, L. W. (1992). In Our Nature: The Kenotic Christology of Charles Chauncy. The Harvard Theological Review, 85(2), 217-233.

Griffin, E. M. (1980). Old Brick: Charles Chauncy of Boston, 1705-1787. University of Minnesota Press.

Gura, P. F. (2005). Jonathan Edwards: America's Evangelical. Hill and Wang.

Haakonssen, Knud (1985). Natural Law and the Scottish Enlightenment. Man and Nature /L'homme et la Nature, 4, 47-80.

Hall, D. (2002). Orthodoxy and Heterodoxy on Trial: A Review Essay. The Harvard Theological Review, 95(4), 437-452. https://doi.org/10.1017/ S0017816002000287

Helm, P. (2009). John Calvin's Ideas. Oxford University Press.

Hofstadter, R. (1960). The American Political Tradition: And the Men Who Made it. Vintage Books. 
Israel, Jonathan (2006). Enlightenment! Which Enlightenment?. Journal of the History of Ideas, 67(3), 523-545.

Kelleter, F. (2009). The Great Awakening and the Enlightenment in

B. Engler, \& O. Scheiding (Eds.), A Companion to American Cultural History: From the Colonial Period to the End of the $19^{\text {th }}$ Century. Wissenschaftlicher Verlag Trier.

Locke, J. (2003). Two Treatises of Government and A Letter Concerning Toleration. Yale University Press.

May, H. F. (1970). The Problem of the American Enlightenment. New Literary History, 1(2), 201-214.

McGrath, A. (2007). Christianity's Dangerous Idea: The Protestant Revolution. A History from the Sixteenth Century to the Twenty-first. HarperCollins Publishers.

Oakes, J. S. (2016). Conservative Revolutionaries: Transformation and Tradition in the Religious and Political Thought of Charles Chauncy and Jonathan Mayhew. Wipf and Stock Publishers.

Reichley, A. J. (1985). Religion in American public life. The Brookings Institution. Rhoda, Alan R. (2010). Gratuitous Evil and Divine Providence. Religious Studies, 46(3), 281-302. https://doi.org/10.1017/S0034412509990503

Robinson, D. M. (2011). Conrad Wright and the Course of American Intellectual History. Journal of Unitarian Universalist History, 35, 25-30.

Shapiro, I. (2003). Locke's Democratic Theory in J. Locke (Ed.), Two Treatises of Government and A Letter Concerning Toleration. Yale University Press.

Skinner, Q. (1993). Los fundamentos del pensamiento político moderno. II. Fondo de Cultura Económica.

Wald, K. D. (1992). Religion and Politics in the United States. Congressional Quarterly Inc.

Wilson, R.J. (1984). The Benevolent Deity: Ebenezer Gay and the Rise of Rational Religion in New England, 1696-1787. The University of Pennsylvania Press. Winship, M. P. (2011). Defining Puritanism in Restoration England: Richard Baxter and Others Respond to A Friendly Debate'. The Historical Journal, 54(3), 689-715.

Zinn, H. (2010). A People's History of the United States. HarperCollins Publishers. 